\title{
Higher Education and Indigenous Nationalities: Challenges for Inclusion in the Ecuadorian Amazonian Region
}

\author{
Rosaura Gutiérrez ${ }^{1}$, Elisa López ${ }^{1}$, Luis Llambí2,3, Thomas May , Alina Ramírez \\ Jairo Tocancipá-Falla ${ }^{2}$ \\ ${ }^{1}$ Universidad Estatal Amazónica (UEA), Puyo, Ecuador \\ ${ }^{2}$ Becario de Investigación Prometeo, Universidad Estatal Amazónica (UEA), Puyo, Ecuador \\ ${ }^{3}$ FLACSO, Quito, Ecuador \\ Email: jtocancipa@unicauca.edu.co
}

Received 24 February 2015; accepted 1 June 2015; published 4 June 2015

Copyright $(2015$ by authors and Scientific Research Publishing Inc.

This work is licensed under the Creative Commons Attribution International License (CC BY).

http://creativecommons.org/licenses/by/4.0/

(c) (i) Open Access

\begin{abstract}
The new constitution of Ecuador gives importance to the less privileged social sectors such as indigenous peoples having access to Higher Education, thus responding to the claims of these individuals and their leaders. However, the example of the Universidad Estatal Amazónica (UEA), a university of the Ecuatorian Amazonian region, suggests that a bias exists against the access of indigenous students, due to multiple factors. Results of an empirical study with recently admitted students of this university indicate that indigenous students have more difficulties in passing the admissions test known as the National Higher Education Exam (ENES by its Spanish acronym) of the Secretary of Higher Education (SENESCYT), due to a less than perfect knowledge of the Spanish language which generally is not their mother tongue, not having access to specific test preparatory materials focused on the main areas of this test (mainly language skills and mathematical-abstract skills), a lack of specific information technology skills necessary for this test, and an absence of a reliable IT infrastructure. In words of one student "many communities in the forest lack of material conditions and good level of education to have access to the University". Anxiety in situations of examination did not have significant effect on the exclusion of indigenous students. Beyond the biases which can be shown empirically, it is necessary to elucidate some basic questions about the access of indigenous people to Higher Education: Is it more important that young indigenous people have better access to Higher Education in order to access higher positions in mainstream society even when in conflict with their ancestral values, or is it more important that Higher Education leads to increased autonomy and strengthened indigenous communities?
\end{abstract}

\section{Keywords}

Indigenous Nationalities of Ecuatorian Amazon, Bias against Insertion in Higher Education, 
Factors of Infrastructure, Language, Quality of Secondary Education, Cultural Context, Admission Exam

\section{Introduction}

For a sustainable development process, as it is defined in the National Plan for Good Living of Ecuador, it is necessary, among many other factors, to focus on the quality of Higher Education, as well as in the inclusion of society's less privileged sectors. Despite some advances in Latin America in terms of including vulnerable sectors in Higher Education, some problems still remain (Mato 2012), especially those related to cultural and social factors impinging upon academic achievements and to the insertion and the permanence in the Higher Education sector (Trucchia, 2013; Cuji, 2011).

In the countries of the Amazon basin, Ecuador being one of them, it is necessary to take into account its pluricultural traits, the diversity of indigenous societies with cultures which are different to the Western society. Ecuador has 14 indigenous nationalities in the whole country. In the Amazonian basin, integrated by six provinces (Sucumbíos, Orellana, Napo, Pastaza, Morona-Santiago and Zamora Chinchipe), there are ten of them, grouping together the major number in Ecuador. According to the national data census of 2010, in Pastaza, where this research took place, there were 33,339 indigenous people belonging to seven nationalities (achuar, andwa, kichwa, sapara, shiwiar, shuar, y waodani) and 48,957 creole or mestizos population (Neves et al., 2003). This corresponds to a rate of $40.5 \%$ of indigenous people at the province level in Pastaza.

Indigenous and Western societies are different not only because of language, but also because of their specific worldviews and some basic assumptions related to epistemology. In this sense, the Delors report (Delors, 1996) and the UNICEF (2012) proposes a dialogue between different cultures of knowledge, sharing the research results and the indigenous peoples' knowledge between them, as well as with the Western culture, by means of mutual and permanent learning processes.

In the same vein, the Article 27 of the 2008 Ecuadorian National Constitution indicates that: "Education is indispensable for knowledge, the achievement of rights and the construction of a sovereign country, and it conforms to a strategic axis for national development”

(http://www.asambleanacional.gov.ec/documentos/constitucion_de bolsillo.pdf, last checked on 18th of February 2015). However, the social reality shows a different picture and according to qualitative data, there is increasing evidence that a considerable number of youth that achieve secondary education do not reach a stable insertion into the University, either because they do not succeed in the admission process, or because they abandon university studies later on. According to some researchers (Reynaga, 2013, quoting Penaflor and Jara 2009), in order to fight against social and cultural discrimination and exclusion in Higher Education for vulnerable sectors of population, it is necessary to promote a respectful attitude to the environment, equity and overall cultural pertinence, throughout the admission process.

A major problem in social research on indigenous education is the lack of data. Only a couple of years ago, the Ecuadorian government began a national system of monitoring the access to the university through the Sistema National de Nivelación y Admisiones (SNNA). Success or failure at the academic level is influenced by a set of psychological-social factors, which among others include, motivational aspects, their capacity to continue to reach the goal, (Barcas et al., 2007; Gaxiola et al., 2012; Valdez y Pujol, 2012; Valle et al., 2010), and their ability to overcome their fearsfrom being evaluated and manage stress (also called social anxiety) (Robles et al, 2008). It is therefore necessary to achieve an acceptable knowledge of the perceptions that both male and female students have about themselves in relation to their own study expectatives, and what they appreciate in relation to their different social and cultural origins, as well as the trajectory to their chosen careers (elected or not), and to the motivation which led them to the university. It is also important to know more about the opinions and criteria of the students in relation to the National Higher Education Exam (ENES by its Spanish acronym), and what they suggest to the prospective students as well as to the authorities. Thus, the motivational and emotional aspects must be taken into consideration when designing the actions to be taken, in both individual and group activities, and also because of the links which emerge among those belonging to indigenous nationalities vis-àvis those which arrive from urban environments with different types of social, economic, cultural and moral characteristics. 
The National Exam for Higher Education (ENES), according to the document published in its Web page (http://www.snna.gob.ec/wp-content/themes/institucion/normativa_menu.php, last checked on 18th of February, page 1), defines it as "an aptitudinal evaluation of low sensibility to the formal education, since it is not directly linked to the middle studies plans. It is an exam of higher personal impact, given the transcendence that this evaluation determines in the decision of each candidate. The ENES evaluates basic aptitudes for learning by means of diverse questions, named as items, and then sub-divided into 40 verbal aptitude aspects, 40 numeral scores and 40 abstract reasoning items". Those who do not obtain a competitive score will not be accepted into the country's public universities and will have to postulate again, choosing among three different options. Even though the Ecuadorian government is aware of the cultural factors involved in access to Higher Education; the organic law for Higher Education (LOES in Spanish) of 2010, for example acknowledges cultural diversity and ancestral knowledge. This normative, in practical terms, is still far away from concrete actions, strategies and results (Cují, 2012).

One of the actions recently undertaken by Tocancipá Falla (2014), anthropologist of the Senescyt-Prometeo program $^{1}$, actually assigned to the UEA, was meeting with the youth of different nationalities, with whom he perceived had technical limitations for accessing the Registry System in the virtual platform of SENESCYT's National System of Levelling and Admission (SNNA). According to the perception of this researcher, both the language employed and the cognitive elements involved in the test were not adapted to the environmental and cultural conditions of the communities of the different nationalities, thus limiting their members' access to Higher Education. Even some questions requesting knowledge about the social and cultural environment of the different applicants were entirely misplaced. For example, some questions asked were related about the time devoted to activities of visiting a museum or going to the cinema. It is clear that these questions were absolutely out of context for a youth coming and living in the Amazonian forest. This data is recorded by the national agencies in order to monitoring the social and cultural environment of the youngsters, but ironically with decontextualized questions, in the case of indigenous nationalities. These questions were asked in the second period of 2014, for the first period of 2015, and due to the recommendation of the researcher to the agency in charge of the exam, a set of questions like this were drawn.

At the regional level, the Ecuadorian Amazonian basin has two universities, IKIAM-based in Tena, capital of the Napo province - and the Universidad Estatal Amazónica (UEA), based in Puyo, capital of the Pastaza, province. The UEA was created in 2002 and offers four programs of research and formation: tourism, environmental sciences, agriculture and livestock, and agroindustrial sciences. The University's government objective mentions: "To develop their activities to achieve its objectives with increasing levels of quality, academic excellence and pertinence", which is accompanied by its teaching objective: "To develop professional leaders of the highest academic quality and technical, scientific and humanistic credentials, undertaking transcendental human values and with the capacity to achieve them in a globalized environment" (www.uea.eu.ec, last checked on October 18, 2014).

Pastaza is the largest province of the Ecuadorian Amazonian basin in territory terms. It received its name from the Pastaza River, which it borders to the south the Morona Santiago province. Its capital city is Puyo. To the North its limits are the provinces of Napo and Orellana, to the East Perú (Loreto province) and to the West the province of Tungurahua. Pastaza is an area of high volume of pluviometric precipitation through the whole year. The temperature varies from $18^{\circ}$ to $24^{\circ}$ degrees. Some of the rivers to the province are: Pastaza, Puyo and Curaray. The province extends $29.773 \mathrm{Km}^{2}$, and is located in the center of the Ecuadorian Amazon Region, between the geographic coordinates $1^{\circ} 10$ South, $78^{\circ} 10$ West; and $2^{\circ} 35$ South and $76^{\circ} 40$ West (www.uea.eu.ec, last checked on December 2014). Pastaza is a province with an important touristic potential because of its jungles and rivers, and a highly diverse flora and fauna. It has a large variety of human communities, called nationalities. Corresponding to this institutional framework, one of the main indigenous nationalities' claims is access of their youth to the University, and the recognition of their ancestral knowledge as belonging to universal knowledge in equal standing to scientific knowledge.

The goal of this research is to examine the social characteristics of the students which enter UEA at Puyo, and the factors which determine their possibilities to succeed in the ENES tests, as well as to determine the possible biases that hinder entrance into the Higher Educational system by indigenous youth, including the possible so-

${ }^{1}$ Prometeo is a programme undertaken by the Ecuadorian government in which worldwide academics and researchers are invited to have a short or middle term stance in any university in order to contribute in research and academic process in the host institution (see

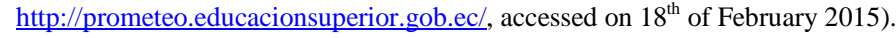


cial and cultural systemic factors, and particularly those which are related to their household, and to the role of anxiety as a mediating factor in these processes. Stemming from its results, the goal is also to propose strategies, among which the design of a more in depth study, in order to further alternative solutions for the problems encountered by both the institutions and the indigenous nationalities. In what follows, we present main aspects in methodological terms, the results and some preliminary and conclusive remarks of this pioneer research in the Ecuadorian Amazonian region.

\section{Research Methodology of This Study}

The methodology in this research combines both qualitative and quantitative data. In the first case, participating in various meetings with leaders of the seven nationalities were spaces for discussion and analysis of the conditions on access of youth in Higher Education in Ecuador. In quantitative terms, the universe was defined as a set of students that in the period 2014-2015 were undertaking the first three academic periods in all the four careers that the UEA was offering, and those that at that moment were taking the leveling course. As an educational policy, the Ecuadorian Education Ministry demands that once the student passes the ENES exam, it should present another exam to determine the level of capacity to enter at the university level. If the student passes this exam, sh/e is allowed to start immediately the career's programme, otherwise sh/e should take the levelling course.

The total amount of students participating in the survey was of 1076, being 571 of them (53.0\%) involved in the levelling course. During the second half of October and November 2014, a survey and the BFNE-acronym in English for Brief Fear of Negative Evaluation scale-were applied to 651 of them and corresponding to the $60.5 \%$ of the total. The sampling was made at convenience, according to the criteria of those who were present in the classroom. Age groups were identified as follows: up to 17 years old corresponded to the $3.5 \%, 18$ to 20 years old were the $72.0 \%, 21$ to 25 years old the $21.4 \%, 26$ to 30 years old the $2.6 \%$ and over 31 years old the $0.5 \%$.

The survey consisted of a single questionnaire of 41 items addressed to know the geographical origins of each student, the social context of their families, school, nationality, the kind of support provided by their parents, the student's motivation to enter the university, and other social and psychological traits. The survey consisted of various types of questions, both open and closed, and of double and multiple options.

The BFNE had been originally elaborated in English by Watson \& Friend (1969), was adapted to the context of the Spanish language by a group of Spanish researchers, and validated with a group of 122 individuals who had been clinically labelled with the diagnostic of social phobia. The Spanish version of the BFNE has 12 items, and responses are scored from 1 to 5 (Cruz et al., 2013).

In addition to the survey, a collection of primary and secondary data was made on the topic, reviewing in particular previous research results, interviews with lecturers and the responsible of the National Exam Service (SNNA) of the UEA, UEA's IT department, Prometeo researchers, and some students that previously had already applied to the ENES. All these elements, did allow us to elaborate a framework to operationalize these variables that then were validated by a technical team.

For the construction of the questionnaire, the model of Artunduaga $(2003,2008)$ was used, which was adapted to the present social and cultural context. The questionnaire was revised by a team of experts, who suggested some modifications, and then was applied to a pilot group of 22 students, who also made suggestions, which were used to re-adapt it, before applying it in a general manner. Permission of the coordinators of the different careers, of the academic teachers and of the participating students was obtained before applying the questionnaire. The time of application varied between 20 and 40 minutes, and a group of students was assisting in this process.

Once the questionnaires were applied, their data was analyzed using a SPSS version 18.0 (PASW Statistics 18). Responses to open questions were categorized through the elaboration of codes and questionnaire data. The BFNE scale was analysed by a descriptive statistical method. After this, different statistical analyses were conducted: chi square $\left(\chi^{2}\right)$, with contingencies tables of 2 by 2, U-test of Mann and Whitney for the significance of differences, and Spearman rank order correlations (R). These non-parametric tests were applied for the reason that most variables were presented in alternative, nominal or ordinal scales. For some variables presented in continuous numerical scales, like final marks in the secondary school, and the ENES results, parametric tests such as the Pearson (r) correlation and Student's t-test were employed to establish the significance of compara- 
tive differences. A confidence limit of an error probability of $p=0.05$ was adopted to consider that differences and correlations are significant.

\section{Main Results and Questions}

Concerning to the origins, the results indicated that the $71.0 \%$ came from the six Amazonian provinces of Ecuador, with the majority from the Pastaza province (35.0\%). 82.0\% of new students at the University including those in their three first semesters also came from Pastaza, and its four neighbouring provinces: Napo, Tungurahua, Santiago Morona y Orellana. Tungurahua, however, is the only province that does not belong to the Amazonian region, but to the Andean range (known in Ecuador as La Sierra). Regarding their choice of UEA versus other universities in the country, the results were as follows: For $42.2 \%$, the UEA was their first option, for $22.8 \%$ it was their second option; and for $14.0 \%$ their third option. The motives for these selections were: "living closer to the university" (26.0\%), "the kind of careers offered by the institution" (22.5\%), "the quality of academic services" (118\%); and "the university's prestige" (10.6\%). The first option is in accord with the fact that in most cases $(97.9 \%)$ the parents' support was crucial. $63.9 \%$ mentioned that their parent's support was moral and economic. 80.7\%, indicated that the motivation to begin Higher Education studies was supported by their parents or brothers/sisters. This data suggests that family support is one of the major factors for embarking in Higher Education. An important factor is that most students come from a family without academic tradition, although $16.4 \%$ of fathers and $20,5 \%$ of mothers have a high level of instruction with Higher Education, and in some cases with postgraduate courses. A significant portion of fathers (42.6\%) and mothers (40.7\%) had only finished basic or primary education. According to this, $21 \%$ of fathers and $24.1 \%$ of mothers were devoted to academic and technical activities, while the majority of fathers were working in the agricultural and livestock sector, transport, unskilled services, commerce and building; and most mothers were considered housewives, although some had small businesses (9.4\%).

In relation to the scores reached in the ENES test, "mestizos" (740.7 points) surpassed those belonging to indigenous nationalities (687.8). However, we lack data concerning the percentage of those who did not pass the ENES test, and posible differences between mestizos and indigenous nationalities. In general, this result shows differences not only at the regional, but also at the national level. In terms of the students' preparation, we found that a major portion of mestizos (32\%) indicated that they had used ENES' simulacra tests as related to the $20.0 \%$ of the indigenous nationalities youth. Additionally, a major proportion of mestizo aspirants (43.0\%) enrolled in private classes in preparation for the ENES exam versus (33.0\%) of the indigenous youth. With reference to the support provided by schools in preparation for the ENES exam, differences were also considerable: $50 \%$ of young mestizos versus $39.0 \%$ of indigenous. In all cases, differences were statistically significant according to Student's t-test.

According to these statistical data, it is important to question to what extent secondary education provides good academic preparation for the ENES exam and for university life. This data was confirmed through sustained dialogue with leaders of the seven nationalities who mentioned the lack of reasonable conditions, and teachers' capabilities to provide good educational quality in the Amazonian region, especially those who live deep in the forest. Our research also showed that those aspirants, mainly mestizos, who have close supervision by teachers and access to electronic resources (e.g. a good internet service), have a better chances to succeed in the ENES text than those who do not.

From the beginning of the admission of students in the UEA in 2004, when the percentage of indigenous nationalites in the new students was near 10\%, until the 2011/12 semester, when this rate reached a value of nearly $20 \%$, there was a constant increase of the proportion of indigenous students newly admitted in the UEA. In the first semester of 2012, the percentage decreased again to $17 \%$, and from this date onward, which coincides with the introduction of the ENES test, the proportion of students from indigenous nationalities maintains itself near this level, except for the second semester of 2013. At this moment, a sudden increase to $25 \%$ can be observed, at the same time when visits of motivation and ENES training to the high schools were established, a practise that further on was abolished again on demand of the high schools. Another factor with a possible incidence is the increase of the score in the ENES test which is required for having access to Higher Education from 600 to 650. For the last two semesters, the rate of indigenous nationalities among the new students descended to $18 \%$ and $16 \%$, respectively.

Concerning the BFNE survey, we found that the $64.4 \%$ expressed an adequate management of fear and social 
anxiety, while the rest manifested a considerable level of fear of a negative evaluation. In relation to the nationalities and mestizos populations, there were no significant differences among them. It is also important to notice that this interpretation is not complete, as the instrument has not been contextually validated (Reece, 2006). This exercise is, thus, only an initial approach that deserves a deeper exam, in particular for the Amazonian region.

During the survey, aspirants had some recommendations to the National System of Levelling, to themselves as young aspirants and the UEA, which are important to remark. Thus $35.8 \%$ expressed the need for taking preparatory training courses, from which $33.2 \%$ suggested that these courses should be organized by the high schools, focusing on the three areas of the ENES exam. The recommendations for the young aspirants manifested a need for perseverance in study, a better disposition to study, and to be calm and patient to reach the best results. The 8\% indicates that the UEA should provide more information concerning careers and establish a better link with the secondary schools as a part of the ENES exam process.

Whereas connectivity and accessing resources have a role to play in explaining why some young indigenous who live in the forest cannot perform properly in the ENES exam, there are other cultural, social, language, and cognitive factors imposed by the exam. Reading comprehension-uses of antonyms and synonyms-mathematical reasoning and abstract reasoning, are the components of the exam, and in all of themkichwas and shuar indigenous youth had comprehension difficulties; facts that can also be explained by the limitations and low quality in secondary education. Most of the classes taken by those youngsters are given in their native languages. In conversation with directives of the National System for the ENES exam, they expressed that the test cannot be changed because all young are equals in Ecuador as they participate in equal conditions. However, this principle is more rhetorical and wrongly interpreted as the conditions-e.g. access to connectivity, level of quality education - are not the same. Most of the indigenous communities lack resources for teaching and the formation of teachers is always a permanent task. For some cases to send a teacher to teach in the jungle is seen as a punishment for his lack of competence or for having a bad performance in a previous period. There is not a clear policy by the government to stimulate and to contribute to the educational environment, bearing in mind the social and cultural factors such as language and contextualised cognitive competences. However the issue is more complex. We do believe that this is not exclusively about changing the ENES exam; it is more about the conceptual framework that crosses the basic and secondary education and goes directly to the Higher Education. The university system is also affected and in many respects must change its approach to Higher Education in a multicultural context.

From here we would like to conclude with some questions, which Schkolnik (2005) also has advanced in terms of labour insertion of young professionals in their cultural context. First of all, what kind of education at different levels is required in the Amazonian region of Ecuador? Second, and bearing in mind the view of strengthening multiculturalism in the Amazonian region, what kinds of professionals are needed by the indigenous nationalities? Is the professionalism formed in the university system an obligated course for young generations? Third, there is the question about the role of the indigenous authorities in all this. In which ways can the indigenous authorities affect the educational system with new proposals?, To what extent can Planes de Vida ${ }^{2}$ lead to change in the educational system? What is the role of the UEA in a new view of the educational system that respects the cultural diversity in the amazon? How can the careers offered at the university contribute to strengthening the cultural diversity of indigenous nationalities?

A final word concerning other social groups deserves attention. In this paper we have emphasised the case of indigenous nationalities, with scant attention to mestizos who also contribute to this multicultural environment. Some youth we found in different contexts in Puyo revealed a similar or worse situation to that of the indigenous nationalities. In this sense it is interesting to mention the huge number of young cab drivers in the town of Puyowho decided not to enter in the university system. Likewise young indigenous showed flaws in the educational system. They reckon that a better education in Puyo is required, something that contrast with better performances carried out by aspirants from the Andean zone-the Sierra—or in the capital, Quito. Further research, comparing both cases of young aspirants attempting to enter in the Higher Education system, also deserves attention. It is desirable here that this kind of investigation be participative with those actors who are crucial in the comprehension and change of their own condition.

\footnotetext{
${ }^{2}$ The Planes de Vida are a set of programmes and activities designed by the indigenous nationalities in order to organise change and identity in their lives. These Planes in many ways are a response to the growing pressure from the State, NGO, the market, and multinational institutions for introduce new forms of life presented as “development” in the Amazon and elsewhere, considered places lagging behind modernity.
} 


\section{Concluding Remarks}

As an outcome of the present study, important information was generated to coordinate activities of applied research, where the academic sector and indigenous nationalities together undertake reflections and dialogue, in search of real inclusión and without rethorics.

First of all, it is necessary to profundize in different senses on the subject of including and excluding factors of students of different procedences in the Higher Education sector, in the context of the Ecuatorian Amazon and of the Universidad Estatal Amazónica (UEA). For this purpose it is important to transcend the frame of the university and to focus as well on high school students who did not have the opportunity to access to Higher Education, for not having reached the score required in the ENES exam, or for economic or family or other reasons.

In this context, it is important not only to focus on cognitive aspects, but also to take into account, in a more fundamental way, aspects related with the motivation of the students to undertake Higher Education studies, and the perspectives for them. As the Systemic Pedagogy points out, "the success is your history", and in this, systemic relations, lealties and permissions to advance further than the ancestors have a role to play (Olvera, 1999; Olvera et al. 2001; Cordero, 2012), which implies research with a wide view, focusing on these occult factors and processes.

In the same way, it is necessary to continue watching and accompanying the situation of the new cohortes of students, the admission process, students who did not have problems to enter at their first intent, and students who did not achieve to get inserted into Higher Education. Methodology and instruments of data collection will to be revised and validated, and other techniques will to be incorporated, as well as other variables.

Partnering with the nationalities and institutions in the research process, demands a suitable and trustworthy environment for collecting data and sharing the results with the actors (local, regional and national authorities in the educational system, indigenous authorities, and young aspirants amongst others). A proposal that emerged in this research was the need for creating an observatory for monitoring the access at the Higher Educational system in the Amazonian region; an idea that can be promoted by the UEA with other central and regional authorities in charge of the secondary system and the indigenous nationalities. In which nationalities is access to Higher Education more feasible? In which is it not, and why? Are questions that this Observatory can address.

We do believe that the accomplishment of these challenges will allow the actors to better know their own limitations and achievements. Surely, a better knowledge of their own context will be profitable, not only for improving levels of inclusion into the Higher Education system, but also for a better understanding of what kind of education is needed for an important strategic region such as the Amazon.

\section{Acknowledgements}

We would like to thanks to the students at Universidad Estatal Amazónica (UEA) that participated in this research and the authorities and the university council of the UEA and Cauca University (Colombia) for the support in assigning time for this research. Becarios Prometeo Senescyt-UEA, wish to thanks to the Senescyt, in particular the Prometeo Programme for sponsoring research in Ecuador in the commitment to improve the achievements for the Sumak Kawsay.

\section{References}

Artunduaga Murillo, M. (2003). Situacióneducativa de los universitarioslatinoamericanos de Madrid y sus necesidades de orientaciónuniversitaria. Madrid: Universidad Complutense.

Artunduaga Murillo, M. (2008). Variables queinfluyenen el rendimientoacadémicoen la universidad. Métodos de investigación y diagnosticoeneducación (MIDE). Madrid: Universidad Complutense.

Asamblea Nacional Constituyente (2014). Constitución del Ecuador. http://educacion.gob.ec/wp-content/uploads/downloads/2012/08/Constitucion.pdf

Barcas, L. A., Porto, R. A., Brenlla, B. J. C., Morán, F. H., \& Barca, E. E. (2007). Contextosfamiliares y rendimiento escolar en el alumnado de educaciónsecundaria. INFAD Revista de Psicología, 2, 197-218.

Cordero Ayuso, M. (2012). Manual práctico de pedagogíasistémica: Unitinerario para introducir la miradasistémicaen el Aula. México, D. F.: Centro Universitario Dr. Emilio Cardenas.

Cruz, T. C., Díaz, L. R., Oropeza, L. R., Díaz, R. P., Padilla, B. J., \& Gónzales, R. I. (2013). Temor a la evaluación social 
negativa. Universitas Psychologica, 2, 531-545.

Cuji Llugna, L. F. (2011). Educación superior e interculturalidad. Tesis para obtener el título de Maestríaen Ciencias Socialesconmenciónen Antropología. Quito: Facultad Latinoamericana de Ciencias Sociales (FLACSO), Sede Ecuador.

Cuji, L. F. (2012). Decisiones, omisiones y contradicciones. Interculturalidad y políticaspúblicasen Educación Superior en Ecuador. In D. Mato (Ed.), Educación Superior y pueblos indígenas y afrodescendientesen América Latina. Normas, políticas y prácticas (pp. 207-240). Caracas: Instituto Internacional de la UNESCO para la Educación Superior en América Latina y el Caribe (IESALCUNESCO).

Delors, J. (1996). Informe Unesco. La educaciónencierrauntesoro. Madrid: Santillana.

Gaxiola Romero, J. C., Gónzales Lugo, S., \& Contreras Hérnandez, Z. (2012). Influencia de la resiliencia, metacontexto social en el rendimientoacadémico de bachilleres. Revista Electrónica de Investigación Educativa, 14, 164-181.

Mato, D. (2012) Educación Superior y Pueblos Indígenas y AfrodescendientesenAmérica Latina. Constituciones, Leyes, Políticas Públicas y Prácticas Institucionales. In D. Mato (Ed.), Educación Superior y Pueblos Indígenas y Afrodescendientesen América Latina. Normas, Políticas y Prácticas (pp. 13-98). Caracas: Instituto Internacional de la UNESCO para la Educación Superior en América Latina y el Caribe (IESALC-UNESCO).

Neves, E., Petersen, J. B., Bartone, R. N., \& da Silva, C. A. (2003). Historical and Socio-Cultural Origins of Amazonian Dark Earths. In J. Lehmann (Ed.), Amazonian Dark Earths: Origin, Properties, Management (pp. 29-50). Dordrecht: Springer Netherlands.

Olvera, A. (2009). Pedagogíadel Siglo XX1. El éxitoestuhistoria. México D. F.: PedagogíaSistémica ${ }^{\circledR}$. Centro Universitario Doctor Emilio Cárdenas.

Olvera, A., Travesset, M., \& Parellada, C. (2011). Sintonizandolasmiradas. Soluciones y breves a los conflictos entre escuela y familia. México D. F.: KreatOutsourcing.

Reece, A. (2006). El desconocidopaís de la inteligencia.Temas del mes. Revista Mundo Diners, 27, 14-22.

Robles, G. R., Anahí, E. R., Padilla, A. C., Álvarez, R. M. A., \& Paez, A. F. (2008). Ansiedad social enestudiantesuniversitarios: prevalencia y variables psicosocialesrelacionadas. Psicología Iberoamericana, 16, 54-63.

Schkolnik, M. (2005). Caracterización de la inserciónlaboral de los jóvenes. Santiago de Chile: Publicaciones de lasNacionesUnidas, Serie 104, Políticas Sociales, División de Desarrollo Social.

Secretaría de Educación Superior, Ciencia y Tecnología (Senescyt) (2014). Examen Nacional de Examen para la Educación Superior, ENES. http://www.snna.gob.ec/dw-Pages/Descargas/instructivo\%20ENES\%20new.pdf

Tocancipá Falla, J. (2014). Informe del taller de capacitación de estudiantes de nacionalidadesindígenasqueaspiran a universidades e institutostécnicosecuatorianos. Unpublished Report, Puyo: Universidad Estatal Amazónica.

Trucchia, S. M. (2013). Análisis de los factoresasociados al rendimientoacadémico de los estudiantes de medicina. Ph.D. Thesis, Córdoba: Cordoba University.

UEA (2014). http://www.uea.edu.ec/index.php/course/plan/32-plan/file. Pág. 3-4

UEA (2014). http://www.uea.edu.ec/index.php/inicio/2013-09-24-08-36-52/2013-09-24-08-39-46

UNICEF (2012). Investigaciónaplicadaen la educación intercultural bilingüe y en la educación intercultural intraculturalplurilingüe. Haciauncambio de paradigmaen la investigación. Experiencia del programa EIBAMAZ. Ecuador-BoliviaPerú. Unicef Finlandia. http://www.unicef.org/ecuador/investigacion.pdf

Valdez, E., \& Pujol, L. (2012). Autorregulación y rendimientoacadémicoen la transiciónsecundaria-Universidad. Revista Latinoamericana de CienciasSociales, Niñez y Juventud, 10, 367-378.

Valle, A. A., Rodríguez, S., Cabanach, R. G., Núñez Pérez, J. C., Gonzales Pineda, J. A., \& Rosario, P. (2010). Perfilesmotivacionales y diferenciasen variables afectivas, motivaciones y de logro. Universitas Psychologica, 9, 109-121. 